\title{
A HISTORICAL LOOK AT THE BIOMEDICAL TESTS CONDUCTED BY COSMONAUTS DURING THE ORBITAL FLIGHT SOYUZ 30 / SALYUT 6
}

\author{
Krzysztof S. KLUKOWSKI', Franciszek W. SKIBNIEWSKI ${ }^{2}$ \\ ${ }^{1}$ Institute of Optoelectronics, Military University of Technology, Warsaw, Poland \\ ${ }^{2}$ Military Institute of Aviation Medicine, Warsaw, Poland
}

\author{
Source of support: Own sources \\ Author's address: F. W. Skibniewski, Military Institute of Aviation Medicine, Krasińskiego 54/56 Street, 01-755 Warsaw, \\ Poland, e- mail: fskib@wiml.waw.pl
}

Background: The article presents biomedical experiments conducted by the first Polish cosmonaut, Maj. Mirosław Hermaszewski, with consideration being paid to the conditions and scientific importance of the experiments. Three experiments developed by Polish researchers, titled "Zdrowie" ("Health"), "Kardiolider" ("Cardioleader") and "Smak" ("Taste") are presented in detail. Names of the researchers and designers planning the biomedical experiments to be conducted on board of the SALYUT 6 station as well as the names of the designers of the physiotest, cardioleader and electrogustometer devices are also mentioned. This article is documentary in nature, and its objective is to present the achievements of the Military Institute of Aviation Medicine (MIAM) in the field of space medicine.

Keywords: biomedical experiments during orbital flights, physiotest, cardioleader, electrogustometer

\section{INTRODUCTION}

In 2013, we celebrate the 35th anniversary of the space flight of the first Pole, a 34-year-old Maj. Mirosław Hermaszewski (1978/07/27). Together with Col. Pyotr Klimuk, he conducted a series of successful geophysical, technological, biomedical and psychological experiments on board of the SOYUZ 30 / SALYUT 6 orbital assembly'.

\footnotetext{
1 It should be mentioned that preparations to these experiments were also conducted with Valeri Kubasov and Lt. Col. Zenon Jankowski (a double for M. Hermaszewski). The choice of the crew to conduct the experiments at the orbit was to be made later by the announcement of crews no. 1 and 2 (as decided by the state authorities of Poland and USSR, announced two months before the scheduled flight).
}

These pilots and cosmonauts (Russian-Polish crews) prepared for the conduct of these experiments in the Yuri Gagarin Cosmonaut Training Centre in Zvezdnoy Gorodok, supervised by the specialists from the Military Institute of Aviation Medicine in Warsaw ${ }^{2}$ and the Institute for Biomedical Problems, later renamed to State Research Centre in Moscow $^{3}$. A question arises regarding the origin of the idea to prepare and conduct space experiments in international crew lineups.

\footnotetext{
2 Main study co-ordinator Col. Prof. Stanisław Barański PhD, MD.

3 Main study co-ordinator Gen. Prof. Oleg Georgiyevich Gazenko PhD, MD and Prof. Anatoly Ivanovich Grigorev.
}

Figures: 1 - References: 15 • Full-text PDF: http://www.pjamp.com • Copyright C 2013 Polish Aviation Medicine Society, ul. Krasińskiego 54/56, 01-755 Warsaw, license WIML • Indexation: Index Copernicus, Polish Ministry of Science and Higher Education 
On July 16, 1976, as part of continuation of earlier biological studies conducted under the auspices of the Interkosmos organization, the academies of sciences of the socialist countries signed an agreement regarding participation of pilots-cosmonaut candidates from these countries in manned space flights. Supersonic jet pilots from Czechoslovakia, Poland and German Democratic Republic participated in the first stage of preparation for space flights in years 1976-1978 [7,10].

The selection of candidates with high health parameters and good aviation training reflected potential risks of space flights and needs for master pilotage skills required to operate space vessels SOYUZ 2930-31. For instance, during the trainings of two-man crews in space vessel simulators Zvezdnoy Gorodok, “(...) new and new emergency situations were presented to us. The instructors and trainers seemed to compete for new ideas. They paid much attention for our abilities to cooperate. They required the development of a methodology for mutual supervision of vessel operating tasks so as to ensure maximum safety(...)" [7].

As part of the Interkosmos program, the space station SALYUT 6, orbiting the Earth for 5 years, hosted 9 international crews arriving to carry out research experiments on SOYUZ-type vessels [1].

As regards the training and biomedical experiments conducted by the first Polish cosmonaut, the devices used for these purposes and research programs were designed by our physicians, physiologists and engineers. Collaborative Soviet/Polish and Soviet/Czechoslovakian/Polish experiments were also planned [3,4,5,11].

As part of Soviet/Polish biomedical experiments, equipment and methodology to assess the exertion tolerance of cosmonauts (before, during and after the flight) as well as the taste receptor functions were developed [3]. To this end, three devices designed at the MIAM, i.e. physiotest, cardioleader and electrogustometer, were used. The Polish party have obliged themselves to deliver six of each of these devices to the Cosmonaut Training Centre in Zvezdnoy Gorodok; cardioleader and electrogustometer devices had to be appropriately miniaturized and resistant to mechanical damage, gravity loads, vibrations and temperature changes. The experiments were titled: "Zdrowie" ("Health"), "Kardiolider" ("Cardioleader") and "Smak" ("Taste").

From time's perspective, a question arises regarding the scientific value of these experiments conducted by individuals not directly involved in scientific research as well as regarding potential continuation or expansion. Before attempting to answer thus formulated questions, it is worth to describe the experiments conducted at that time as well as the conditions of space flights lasting 7-10 days.

\section{THE EXPERIMENT “ZDROWIE” (“HEALTH”)}

Earlier studies by Soviet and American authors $[1,14]$ showed that even relatively short stays in microgravity conditions lead to reduced bodily efficiency and tolerance to physical exertion. This is due to the reduced burden on the cardiovascular system, atrophy of selected muscles (mostly those of antigravitational function) as well as the reduction of their endurance and strength. In long-lasting flights, the degree of the reduction in these parameters and the degree of functional changes (sarcopenia, osteopenia) depends on the type, intensity and duration of specific physical exercise. Disturbed perception of stimuli at the gravity receptors leads to space motion sickness $[1,6,14]$. There is no doubt that the above changes impede readaptation to the Earth gravity conditions after returning from the orbital mission. The experiment "Zdrowie" ("Health") involved measurements of physical efficiency (using a cycloergometer) before the flight as well as shortly after landing. The "Physiotest" device was used to analyze the ECG records, heart rate, automated blood pressure measurements, respiratory rates, lung ventilation and deep body temperature.

An important characteristic of physiological measurements was that they were performed in cardiovascular steady state ensured by a feedback loop between the heart rate (HR) and cycloergometer load ( $\mathrm{kGm} / \mathrm{min})$. It is worth to note that this allowed to adjust the exertion load to the current physical efficiency of the cosmonaut (e.g. by maintaining the upper HR limit at or below $150 \mathrm{bpm}$ ). Otherwise, the devices were designed in such a way that following subsequent miniaturization they could be used in microgravity conditions within the space stations during subsequent space missions. It should also be mentioned that returns from long-term orbital flights (as pursued in later periods, e.g. in the MIR space station) were associated with marked impairment of the ability to perform physical efforts and with the socalled entry motion sickness (EMS) [15].

\section{THE EXPERIMENT "KARDIOLIDER" ("CARDIOLEADER")}

As shown by the previous experience of Soviet physiologists and physicians who studied the process of bodily adaptation to microgravity conditions, cosmonauts taking part in long flights should systematically perform endurance and strength exercises (cycloergometer, treadmill, rubber expanders, resistance devices) of optimum intensity (70-80\% of maximum exertion capacity) and duration (ca. 1.5 h) $[1,14]$. When attempting to 
monitor training load in endurance exercises, the best method involved the recording of heart rate $(\mathrm{HR})$ in relation to the load being applied. It is important to identify the efficient training threshold (including the upper threshold) for each cosmonaut, as the values are highly diversified between individuals. Thus, physiologists and engineers at the MIAM designed an electronic device used in sports medicine and known as cardioleader, adapting it to microgravity conditions (weight $250 \mathrm{~g}$, battery-powered). Three leads placed on the chest monitored the heart rate, or more specifically, the training range (e.g. 120-130/140-150 HR), with alarms sounding when the HR range was exceeded in plus or in minus. This allowed the cosmonaut to adjust the training load on the basis of acoustic signals. Cardioleader was also designed to monitor training loads during readaptation to Earth gravity conditions after the flight. On request of MIAM's physiologists, Mirosław Hermaszewski had cardioleader leads on and was undergoing heart rate monitoring nearly throughout the entire flight [7].

\section{THE EXPERIMENT “SMAK" ("TASTE")}

In microgravity conditions, particularly during the first several days in space, one experiences the so-called cephalization of circulation and excess blood within the upper body, including the head and head organs (such as tongue). Stimulation of gastroglossal reflex is also disturbed. Psychological factors and factors related to the composition (taste) of food may not be excluded. This leads to impairment of taste sensations and lack of appetite being reported by the cosmonaut (independently of the space motion sickness). According to previous reports from astro- and cosmonauts, they experienced impairment of the sense of taste or disturbed sensitivity to taste. For instance, the taste of meat was perceived differently than on Earth, and no sour taste was perceived at all. Periodically, complete loss of taste sensations was experienced [11]. The experiments involved the previously known devices used to test the taste sensations, known as electrogustometers. Obviously, the design of the device had to be adapted to microgravity conditions, resistant to vibrations and appropriately miniaturized. The principle of the experiment consisted of inducing taste sensations at the tip of the tongue by stimulating it with electric current (0-200 mA; 27V). The passive electrode was held in one hand, while the active electrode was pressed against the same regions of the tongue tip using the other hand. Taste percep- tion thresholds were determined from 5 measurements on each side of the tongue, with 5-minute intervals to eliminate possible adaptation. Thus, the perception of taste could be compared before and during the flight $[11,12]$.

\section{PSYCHOLOGICAL EXPERIMENTS}

Two space psychology experiments were also designed by MIAM researchers ${ }^{4}$. The first experiment, titled "Relaks" consisted in the assessment of the effect of the relaxation program on the psychophysiological condition of cosmonauts. The other experiment, titled "Test" (conducted in collaboration with the researchers from USSR), included subjective assessments of the psychophysiological condition of the cosmonauts made on the basis of a proprietary self-assessment diary [3,12].

\section{OTHER BIOMEDICAL EXPERIMENTS}

As part of the international experimental program Interkosmos, Mirosław Hermaszewski took part in the following biomedical experiments conducted on board of the SALYUT 6 space station (Col. Zenon Jankowski was also prepared for the conduct of these experiments):

- assessment of the effect of negative pressure in the space suit on changes in the selected cardiovascular parameters “Chybis” („Peewit”), (in collaboration with researchers from USSR);

- reographic measurements of blood being transferred into different body areas during initial adaptation to microgravity conditions (in collaboration with researchers from USSR);

- studies on heat exchange in selected tissues (in collaboration with researchers from Czechoslovakia and USSR)

- the use of polarographic methods in the assessment of oxygen exchange in tissues (in collaborations with researchers from Czechoslovakia and USSR).

These experiments were continued by the crew of the next orbital flight SOYUZ 31 - SALYUT 6: Valeri Bykovski (USSR) and Siegmunt Jahn (GDR) [12].

\section{MICROGRAVITY CONDITIONS AND THE ABILITY TO CONDUCT PHYSICAL TRAINING AND RESEARCH}

Mirosław Hermaszewski remained in orbit for 8 days (190h 03min 04s), orbiting the Earth 126 times. However, only 6 days were available for the conduct of the experiments, as nearly one day was

4 Col. Dr. Romuald Błoszczyński and Maj. Dr. Jan Terelak. 
spent on docking the SOYUZ-30 to the SALYUT- 6 station $^{5}$, and the last day was spent on station detachment and preparation of landing [7]. It should be mentioned that in such short flight periods (8 days), the organisms of the cosmonauts only start to adapt to microgravity conditions, and thus the timing of the experiments was not in harmony with the optimum psychophysical capabilities of the crew [9]. Cosmonauts moved around as cautiously as possible to avoid rapid head movements so as not to induce the space motion sickness (vomiting without forewarning symptoms such as nausea).

On the first day at the station, psychological experiment "Test" and technical experiment "Syrena" ("Siren") ( $\mathrm{Hg}+\mathrm{Cd}+\mathrm{Te}$ combination) were conducted. On the third day, devoted to medical experiments "Kardiolider" ("Cardioleader") and "Smak" ("Taste") experiments were conducted along with the assessment of oxygen metabolism, heat exchange and psychophysical status. On the fourth day, the "Chybis" ("Peewit") experiment was conducted, with $\mathrm{M}$. Hermaszewski being the subject and $\mathrm{P}$. Klimuk being the conductor. The experiment involved controlled episodes of fainting upon increasing the negative pressure forcing blood to escape from the upper body. At the end of the experiment, M. Hermaszewski performed a physical exercise with heart rate monitoring using the cardioleader device. On the same day (after lunch break), the "Smak" ("Taste") experiment was conducted using an electrogustometer. On the fifth day, Czechoslovakian oximeter was used for the measurement of tissue oxygenation (M. Hermaszewski later reported that the work had "upset" his labyrinth). The last experiment "Ziemia" ("The Earth") was conducted using a photographic camera MKF-6. M. Hermaszewski recalled this experiment as follows: "My labyrinth goes crazy, I feel sick" [7].

\section{POTENTIAL BENEFITS OF BIOMEDICAL EXPERIMENTS}

As part of the introduction, it is worth to recall the comment made by the first Polish cosmonaut, Gen. Mirosław Hermaszewski at the 25th anniversary of his space flight. The comment pertained to the docking of the SOYUZ-30 vessel to the SALYUT-6 space station: "A day later, I transferred my emotions and scientific equipment to the space laboratory on board of the SALYUT-6 space sta-

5 Exactly 18 revolutions around the Earth until docking and 2 revolutions for verification of docking hermeticity. tion. It was a great scientific adventure to conduct unique experiments developed by Polish scientists; to this day, I am happy and satisfied of having fulfilled my duties to Poland and the Poles". Celebrating the 65th anniversary of the MIAM, the Commanding Officer Prof. S. Barański remarked that: "(...) One should not forget the large contribution of the Institute in preparation and design of the space flight of the first Polish cosmonaut. Computer-aided methods were used for designing and developing institute's own instrumentation. Of note is the fact that one of the Physiotest devices is currently in use in the MIR space station. This was the main direction of our collaboration in bioastronautics research programs" (Fig. 1) [2].

It should be mentioned that according to the requirements for candidates for the first Polish cosmonaut (1976), the candidate should be a jet plane pilot of outstanding health, resistance to emotional stress, physical fitness, good media contact abilities and abilities to conduct scientific experiments [10]. Therefore, the assumptions were that the flight would be manned not by a typical scientist, but by a high-class pilot capable of both piloting the space vessel and conducting scientific experiments suited to the crew's abilities.

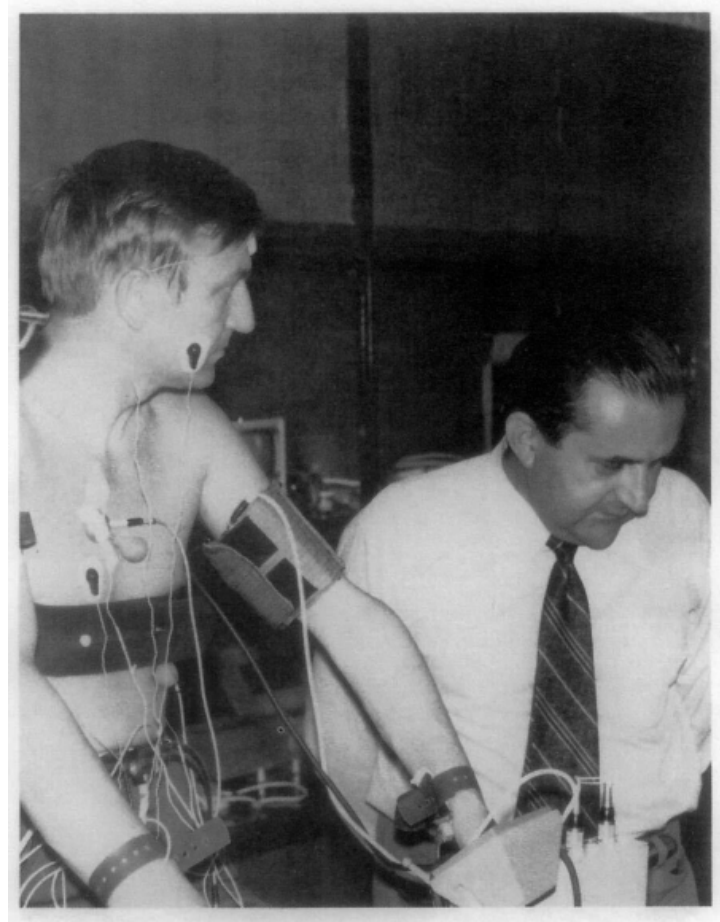

Fig. 1. The Commanding Officer of the Military Institute of Aviation Medicine, Col. Prof. S. Barański conducts experiments using the Physiotest device in Zvezdnoy Gorodok. The subject is Maj. M. Hermaszewski (courtesy of M. Hermaszewski). 
The biomedical experiments conducted on board of the space station SALYUT-6 were preceded by many years of scientific collaboration between specialists of the Military Institute of Aviation Medicine, Institute of Biostructure of the Warsaw Medical Academy and the Department of Applied Physiology of the Medical Research Centre of the Polish Academy of Sciences in Warsaw. It involved experiments on animals taking part in three-week flights on Biosputnik 782 and 936 vessels [13]. From the Soviet side, the studies were co-ordinated by the Institute of Biomedical Problems (IBMP) in Moscow. The main goal of the experiments was to assess the ultrastructure of the myocardium (by means of electron microscopy), skeletal muscles, bones and adrenal glands following a period spent in microgravity conditions. The results of the studies were used for the development of special exercise programs and devices to counter the adverse effects of microgravity conditions in humans [1].

When assessing potential benefits of biomedical experiments conducted by the Polish-Soviet crew of SOYUZ-30, the experiments may be classified as follows:

- establishment of interdisciplinary research teams (experimental physiologists, clinicians, bioengineers, psychologists) conducting research programs at the MIAM;

- control and monitoring of exertion loads in microgravity conditions and upon readaptation to Earth gravity conditions as part of the "Kardiolider" ("Cardioleader") experiment;

- development of an on-board apparatus "Physiotest-4" (capable of working together with the Soviet on-board ergometer WB-3) for physical tests and exercises to be installed on the subsequent (after SALYUT-7) space station MIR (operating for 15 years, from 1986/02/20 to 2001/03/22) as a result of the "Zdrowie" ("Health") experiment;

- establishment of a unique team of MIAM bioengineers (collaborating with the IBMP in Moscow) allowed the team to develop a miniature equipment for the measurement of selected physiological parameters during real life flights in training planes as well as during tests on gravity centrifuges (different profiles of $+\mathrm{Gz}$ accelerations), such as "AGAT" system. These measurements are also carried out for diagnostic and therapeutic purposes upon operation of any type of aircraft, with extension of the test to the post-flight period [12];

- as part of the Polish/Soviet experiment "Chybis" ("Peewit"), peripheral and central circulation mechanisms were studied in low body negative pressure (LBNP). “Chybis" ("Peewit”) pants were used in trainings aimed at increasing the efficiency of vascular mechanisms associated with readaptation to Earth gravity conditions (blood stasis in lower limbs);

- The "Smak" ("Taste") experiment was planned as a pilot experiment to enable the cosmonauts to carry out independent research. The use of specific gustometry was planned at later stages [11]. However, these studies were never continued by MIAM researchers. More advanced gustometry experiments were conducted in Poland in year 2012 at the Faculty of Electronics and Information Technologies of the Warsaw University of Technology using taste potentials induced by bipolar electrogustometry. Objectivity of the method consists in the measurement of electrical activity of the brain in response to stimulation of taste receptors [8].

\section{POLISH PHYSICIANS AND BIOENGINEERS INVOLVED IN THE DEVELOPMENT OF TEST INSTRUMENTATION AND THE DESIGN OF BIOMEDICAL EXPERIMENTS}

Studies conducted in animal models were conducted by Col. Prof. Stanisław Barański PhD, MD (Commanding Officer of the Military Institute of Aviation Medicine, cytophysiologist and aviation medicine specialist), Prof. Kazimierz Ostrowski PhD, MD (Director of the Institute of Biostructure, Medical University of Warsaw, cytophysiologist), Prof. Wanda Stodolnik-Barańska PhD, MD (researcher at the Institute of Biostructure, Warsaw Medical Academy, cytophysiologist), Prof. Stanisław Kozłowski PhD, MD (Department of Physiology, Medical Research Centre of the Polish Academy of Sciences in Warsaw, specialist in applied physiology and extreme environmental conditions). "Zdrowie" ("Health") and "Kardiolider" ("Cardioleader") experiments were co-authored by Prof. S. Barański PhD, MD, Prof. S. Kozłowski PhD, MD, Asst. Prof. Zbigniew Sarol PhD, MD, Jerzy Stendera MSc, Franciszek W. Skibniewski PhD, Augustyn J. Piórko MSc, Włodzimierz Walichnowski PhD, Witold Staniszewski (technician).

"Electrogustometer" experiment was prepared by Prof. Janusza Kubiczkowa, PhD, MD, Ryszard Saganiak (Eng.), F. Skibniewski, PhD and Jerzy Stendera, MSc. 


\section{AUTHORS' DECLARATION:}

Study Design: Krzysztof S. Klukowski, Franciszek W. Skibniewski; Data Collection: Krzysztof S. Klukowski, Franciszek W. Skibniewski; Manuscript Preparation: Krzysztof S. Klukowski, Franciszek W. Skibniewski; Funds Collection: Krzysztof S. Klukowski, Franciszek W. Skibniewski. The Authors declare that there is no conflict of interest.

\section{REFERENCES}

1. Antinov, W.W., Grigoryev, A.I., Litch Khantun K. (1997) Chelovek v kosmicheskom polyote. Moscow: Nauka.

2. Barański, S. (1993) 65 lat Wojskowego instytutu Medycyny Lotniczej. Medycyna Lotnicza. 3-4 (120-121). 9-24.

3. Barański, S., Błoszczyński, R., Hermaszewski, M., Kubiczkowa, J., Piórko, A., Saganiak, W., Sarol, Z., Skibniewski, F., Stendera, J., Walichnowski, W. (1979) Badania stanu psychofizjologicznego kosmonautów podczas lotu orbitalnego kompleksu kosmicznego „SOJUZ 30 - SALUT 6”. Badania elektrogustometryczne w locie orbitalnym. Metoda i aparatura do badania zdolności wysiłkowej kosmonautów. Zastosowanie kardiolidera do kontroli czynności serca kosmonauty podczas treningu fizycznego oraz w ubiorze podciśnieniowym w stacji orbitalnej „SALUT 6”. Postępy Astronautyki. 12 (4). 11-50.

4. Barański, S., Kubiczkowa, J., Piórko, A., Skibniewski, F., Bryanov, I., Milova, E.P., Nefedova, M.V., Yakovleva, I.J. (1983) Electrogustometric Investigations During Manned Space Flight. Aviat. Space Environ. Med. 54 (1). 1-5.

5. Barański, S., Skibniewski, F. (1983) System oceny stanu psychofizycznego kosmonautów w warunkach kontrolowanego treningu fizycznego. Medycyna Lotnicza. 1 (78). 67-77.

6. Clement, G. (2005) Fundamentals of Space Medicine. Dordrecht: Springer.

7. Hermaszewski, M. (2011) Ciężar nieważkości. Opowieść pilota-kosmonauty. 2nd ed. Cracow: Towarzystwo Autorów i Wydawców Prac Naukowych UNIVERSITAS.

8. Kamiński, T. (2012) Elektrogustometryczne potencjały wywołane mózgu. Doctoral dissertation, Warsaw University of Technology, Warsaw, Poland.

9. Kennedy, C.H., Kay, G.G. (2013) Aeromedical psychology. Burlington: ASHGATE.

10. Klukowski, K. (2008) 30. rocznica lotu Polaka w Kosmos. Polski Przegląd Medycyny Lotniczej. 2 (14). $125-133$.

11. Kubiczkowa, J., Skibniewski, F. (1979) Przydatność elektrogustometrii w medycynie lotniczej i kosmicznej. Otolaryngol. Pol. XXXIII (2). 61-66.

12. Kwarecki, K. (1993) Charakterystyka wybranych kierunków naukowo-badawczych rozwijanych w Wojskowym Instytucie Medyny Lotniczej. Medycyna Lotnicza. 3-4 (120-121). 25- 30.

13. Kwarecki, K., Terelak J. (1980) Medycyna i psychologia kosmiczna. Warsaw: Wiedza Powszechna.

14. Nikogossian, A. E., Parker, J.E. (1982) Space physiology and medicine. NASA SP. 447.

15. Seedhouse, E. (2010) Prepare for Launch. Chichester: Springer, Praxis Publishing.

Cite this article as: Klukowski KS, Skibniewski FW: A Historical Look at the Biomedical Tests Conducted by Cosmonauts During the Orbital Flight Soyuz 30/Salyut 6. Pol J Aviat Med Psychol, 2013; 19(3): 17-22. 